\title{
PRINSIP IKRÂM AL-MUSLIM GERAKAN DAKWAH JAMAAH TABLIGH DALAM MEMBANGUN MASYARAKAT RELIGIUS DI TEMBORO MAGETAN
}

\author{
Moh. Yusuf \\ Sekolah Tinggi Agama Islam Ma'arif Kendal Ngawi, Indonesia \\ E-mail: tazaissuf@gmail.com
}

\begin{abstract}
This article explores the Da'wah Movement of Jamaah Tabligh in building religious community in Temboro Magetan. One one of the main teachings is the principle of ikerâm al-Muslim (honoring and respecting every Muslim). The principle makes the missionary movement acceptable to the Muslim community widely. This principle is really important for the creation of the unity of the Muslims in the name of ukhuwwah Islamîyah (Islamic brotherhood). This principle prohibits a believer to guestion the religious stream, political choice, position, and social status and background of the individual community of individual Muslims. The principle eventually enables the tabligh community to adapt to different environments and preaching fileds in building religious community. Initially, people did not respond the tabligh mission in Temboro, but it did not dampen the spirit of tablighis to preach. They remain persistent and patient in fighting for the truth of Islam. Their goal is to liven the passion of high religiosity.
\end{abstract}

Keywords: The Da'wah Movement; the tabligh community; ikerâm al-Muslim; ukhuwwah Islâmîyah.

\section{Pendahuluan}

Dakwah merupakan bagian tugas agama dalam menjaga keberlangsungan ajaran serta tujuannya. Beragam aliran pemahaman keagamaan muncul di tengah-tengah umat yang kemudian juga melahirkan banyak pemikiran dan varian gerakan dakwah didalamnya. Tujuan dakwah adalah demi tersebar serta terjaminnya pengamalan suatu ajaran agama guna membentuk prilaku masyarakat menjadi berakal budi (beradab). Dalam pandangan agama, masyarakat beradab adalah masyarakat yang taat, yang bersungguh-sungguh menerapkan secara konsisten dan benar ajaran-ajaran agama, dengan mengamalkan 
ajaran agama secara benar maka akan mengantarkan sebuah masyarakat menjadi religius, dengan menjadi masyarakat yang religius maka masyarakat tersebut menuju masyarakat yang (paling mungkin) menjadi masyarakat yang beradab. ${ }^{1} \mathrm{Di}$ antara beragam gerakan dakwah yang lahir dan tumbuh di tengah-tengah kehidupan masyarakat kaum Muslimin adalah dakwah Jamaah Tabligh, gerakan dakwah yang lahir di selatan India, Khandahla, tepatnya di Mewat pada tahun $1925 .^{2}$

Dakwah Jamaah Tabligh, seiring berjalannya waktu, semakin mengalami perkembangan yang pesat dan luas, tidak hanya tersebar luas di India dan di negara-negara tetangganya, seperti Pakistan, dan Banglades, dakwah ini jauh masuk dan di terima oleh berbagai kalangan aliran pemahaman masyarakat Muslim di berbagai negara, bahkan tidak sedikit yang akhirnya masyarakat non-Muslim dengan penuh minat masuk Islam, dan bahkan di antara mereka bersamasama melakukan suruan dakwah ini. ${ }^{3}$

Gerakan dakwah Jamaah Tabligh mulai masuk ke Indonesia sekitar tahun 1952, tetapi pada tahun tersebut belum nampak intensitas gairah dakwahnya, dan baru pada tahun 1974 semarak dakwah ini menunjukkan semangatnya yang tinggi. ${ }^{4}$ Dakwah kemudian terus berkembang pesat di berbagai banyak daerah di Indonesia, tidak terkecuali di Magetan, tepatnya di Temboro. Dakwah Jamaah Tabligh tercatat mulai masuk Temboro, Magetan sekitar tahun 1980an. ${ }^{5}$

Salah satu doktrin terpenting dari ajaran dakwah Jamaah Tabligh ini adalah prinsip ikrâm al-Muslim (menghormati atau memuliakan setiap individu Muslim); ${ }^{6}$ salah satu prinsip yang mengantarkan

\footnotetext{
${ }^{1}$ Masyarakat beradab adalah masyarakat yang bereprilaku santun, berbudaya tinggi, baik dalam pergaulan sehari-hari, dalam berbicara, dalam mencari kebenaran, bahkan dalam mencari rejeki. Lihat Wahyudin dkk., Pendidikan Agama Islam untuk Perguruan Tinggi (Jakarta: Grasindo, 2009), 105.

2 Syid Abu Hasan Ali an-Nadwi, Sejarah Muhammad Ilyas Menggerakkan Jamaah Tabligh Mempelopori Khuruj Fi Sabilillah (Bandung: Pustaka Ramadhan, 2009), 40.

3 Abdurrahman Ahmad As-Sirbuni, Kupas Tuntas Jamaah Tabligh, Vol. 1 (Cirebon: Pustaka Nabawi, Cet. 3, 2010), 42.

${ }^{4}$ Edi Amin, "Dakwah Rahmatan li al-'Alamin Jamaah Tabligh di Kota Jambi", Jurnal Komunikasi Islam, Vol. 2, No. 1 (Juni, 2012), 37.

5 Samsul Munir, Pluralisme Madz̧hab Dakwah Jamaah Tabligh di Kampung Madinah (Yogyakarta: Pustaka Ilmu, 2015), 139.

${ }^{6}$ Budimansyah, "Gerakan Islam Jamaah Tabligh dalam Tinjauan Maqasid al-Din", Jurnal Al-'Adalah, Vol. 10, No. 3 (2012), 265.
} 
gerakan dakwah ini diterima oleh masyarakat Muslim secara luas hingga berkembang sangat pesat. Prinsip ini benar-benar membuka peluang yang besar bagi terciptanya persatuan dan kesatuan kaum Muslimin atas landasan ikhwah islâmîyah (persaudaraan atas nama Islam) di mana prinsip ini melarang seorang mukmin mempermasalahkan aliran pemahaman, pilihan politik, kedudukan, serta latar belakang status sosial individu Muslim lainnya.

\section{Latar Historis Gerakan Dakwah Jamaah Tabligh}

Latar belakang kelahiran gerakan dakwah Jamaah Tabligh tidak lepas dari peran seorang ulama besar yang bernama Maulana Muhammad Ilyas; seorang ulama dari keturunan keluarga yang sangat agamis. ${ }^{7}$ Ketinggian semangat dakwahnya terpacu ketika ia melihat mayoritas masyarakat Muslim Mewat sudah benar-benar jauh dari pengamalan ajaran-ajaran Islam. Masyarakat Muslim Mewat hidup surut ke belakang dalam keberagamaannya, dan bahkan pada titik yang sangat kritis. Adat mereka adalah campuran antara ajaran Islam dan tradisi Hindu. Mereka menikah dengan tatacara mempercampuraduk antara tatacara Islam, adat dan tradisi Hindu, mendatangi kuil, merayakan hari-hari besar Islam dan hari besar Hindu, seperti Holy dan Dilwale, dan gemar hura-hura, menyucikan kuburan orang-orang yang dianggap keramat. ${ }^{8}$

Tradisi Hindu sudah menjadi familiar dan populer dalam masyarakat Muslim Mewat. ${ }^{9}$ Agama Islam hanya tinggal nama saja bagi masyarakat Mewat. Mereka jarang melaksanakan salat atau bahkan sudah tidak lagi salat, dan bahkan mereka merampok serta melakukan perbuatan lainnya yang dilarang oleh agama. Singkatnya, mereka beragama tetapi tidak peduli atau bahkan mengingkari ajaranajaran agamanya. Mereka banyak yang buta huruf dan hidup miskin. Mereka seperti kaum Jahiliah Arab zaman Nabi Muhammad. ${ }^{10}$

Sementara para ahli-ahli agama India disibukkan oleh perselisihan paham tentang amalan-amalan keagamaan yang hanya bersifat furû́y̆ah (cabang) yang tidak pernah kunjung menemukan kepastian titik temu sehingga rasa simpati serta saling menghargai di antara mereka sesama

\footnotetext{
7 Umdatul Hasanah, "Keberadaan Kelompok Jamaah Tabligh dan Reaksi Masyarakat: Perspektif Teori Penyebaran Informasi dan Pengaruh", Jurnal IndoIslamika, Vol. 4, No. 1 (Januari-Juni, 2014), 22.

8 An-Nadwi, Sejarah Muhammad Ilyas, 30-31.

${ }^{9}$ Hasanah, "Keberadaan Kelompok Jamaah Tabligh", 23.

${ }^{10}$ An-Nadwi, Sejarah Muhammad Ilyas, 29-30.
} 
Muslim terangkat dari dalam hati-hati mereka. Mereka saling menyerang satu sama lain dengan tuduhan-tuduhan yang tidak pantas atas amalan-amalan keagamaan masing-masing. ${ }^{11}$ Masyarakat yang menjadi korban, mereka terombang-ambing. Muhammad Ilyas merasakan bahwa masyarakat Muslim ketika itu bagaikan sekumpulan kambing yang kebingunngan mencari arah jalan. Jika pengembala menghalau kambing-kambing mereka dari satu arah ke arah yang lain, maka kambing-kambing itu terhenti karena terhalang oleh larangan dari arah lainnya sampai hingga kemudian kambing-kambing itu terpecah belah lepas dari kumpulannya dan menuju ke arah yang lainnya. ${ }^{12}$

Sistem penjajahan ketika itu baik langsung atau tidak telah ikut andil dalam membentuk pola hidup masyarakat India, tidak terkecuali dalam aspek keberagamaan. Penjajahan Inggris atas India selama kurang lebih 200 tahun telah memberikan pengaruh atas mental serta sikap keberagamaan kaum Muslimin India, termasuk masyarakat Muslim di Mewat. ${ }^{13}$ Berbagai masalah sosial masyarakat yang muncul tidak lepas dari peran serta eksistensi suatu negara. Negara yang terjajah secara jahat tidak akan mampu membangun masyarakat untuk bisa berkembang, kreatif, dan maju. Demikian halnya dengan agama di mana praktik keagamaan tidak akan mampu berjalan tegak jika suatu negara dalam keadaan kacau dan berada dalam suatu ancaman dan cengkeraman. Hal ini tidak terlepas dari kekuasaan yang menjadi alat yang sangat menentukan bagi berkembangnya sebuah ajaran agama maupun kebudayaan. ${ }^{14}$

Memperhatikan potret India secara umum, terlebih di selatan India, khususnya Mewat atas kondisi masyarakat Muslim, Maulana Ilyas berkesimpulan bahwa sangat perlu dan mendesak untuk dilakukan perbaikan yang bersifat permanen di tengah-tengah masyarakat. Di dalam pandangan Maulana Ilyas, berdasarkan pembacaan atas pengalaman-pengalaman sebelumnya, perbaikan untuk menyembuhkan penyakit di atas tidak cukup hanya pada penyembuhan secara perorangan atau membatasi perbaikan kepada golongan atau kelas tertentu dalam masyarakat. Perbaikan akan

${ }^{11}$ Ibid.,168.

12 Ibid., 38-39.

13 Tessa Balasuriya, Teologi Sejarah (Jakarta: Gunung Mulia, Cet. ke-3, 2004), 23-24.

14 Ahmed Kameel Mydin Meera, Perampok. Bangsa-Bangsa: Mengapa Emas Harus Jadi Uang Internasional?, terj. Yulizar Djamaluddin Sanrego NZ (Jakarta: Penerbit Mizan, 2010), 125. 
berhasil apabila iman merasuk ke hati semua anggota masyarakat secara luas. ${ }^{15}$ Pemikiran tersebut melahirkan gerakan dakwah secara jamâ $\hat{\imath} ;$ gerakan dakwah kolektif kepada masyarakat luas.

Pemikiran dakwah di atas diperkuat oleh pengalaman hajinya yang kedua pada 1925. Ketika di Madinah, Maulana Ilyas mendapat ilhâm yang bersis perintah untuk melakukan usaha dakwah, tetapi dalam dirinya ia merasa ragu apakah dirinya mampu untuk mengemban tugas berat tersebut. Namun atas dorongan serta dukungan dan janji setia dari sahabat-sahabatnya, Maulana Ilyas kemudian berketetapan hati melaksanakan usaha dakwah. ${ }^{16}$

Terdapat tiga versi atas ibadah haji kedua Maulana Ilyas yang dinilai sebagai titik tolak atas usaha gerakan dakwah Jamaah Tabligh yang sudah dicetuskannya. Pertama adalah pandangan yang mengatakan bahwa sumber lahir gerakan dakwah Jamaah Tabligh berasal dari mimpi Maulana Ilyas di mana di dalam mimpi tersebut Maulana Ilyas dihadirkan sebuah ayat al-Qur'ân yang terdapat dalam surat Âl 'Imrân ayat $110 .{ }^{17}$ Mimpi tersebut murupakan jawaban atas kerisauan Maulana Ilyas memikirkan strategi dakwah yang "ideal" untuk umat Islam. ${ }^{18}$

Kedua adalah versi yang mengatakan bahwa model dakwah yang dicetuskan oleh Maulana Ilyas tidak murni berasal dari hasil pemikirannya, melainkan berasal dari pemikiran Saî̀d Nursî al-Kurdî atau yang dikenal dengan nama Badî̀ al-Zamân; seorang cendekiawan Muslim yang hidup di Turki pada 1293-1379 H. Maulana Ilyas berinteraksi dengan pimikiran gerakan dakwah ini ketika ia

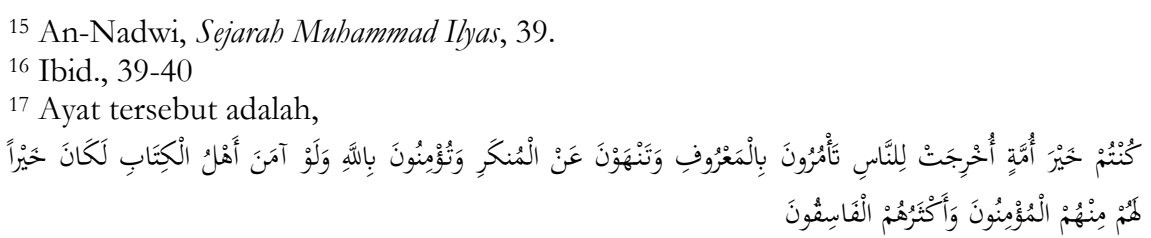

"Kamu adalah umat terbaik yang dikeluarkan (dilahirkan) untuk manusia, menyuruh kepada ma'ruf dan mencegah dari yang munkar, dan kamu beriman kepada Allah. Sekiranya Ahli Kitab beriman tentulah itu lebih baik bagi mereka. Di antara mereka ada yang beriman, dan kebanyakan mereka adalah orang-orang yang fasik." (QS. Ali Imrân [3]: 110). Kata ukhrijat pada ayat tersebut oleh Maulana Ilyas dimaknai khurûj, yaitu "pergi keluar" (dakwah) kepada li al-nâs (manusia). Lihat Muhammad Mayân Muhammad Aslim al-Bâkistânî, Jamâ'at Tablîgh: 'Aqîdatuhâ wa Afkâr Mashâyikhihâ (Madînah: Jâmi‘ah Islâmîyah al-Madînah al-Munawwarah, 1393 H), 45.

18 Abdurrahman Ahmad As-Sirbuni, Kupas Tuntas Jamaah Tabligh, Vol. 3 (Cirebon: Pustaka Nabawi, Cet. 7, 2012), 51. 
melaksanakan ibadah haji. Jadi, kelahiran pemikiran gerakan dakwah ini adalah di Turki sedangkan aplikasi gerakannya dimulai dari India. Hal ini juga tampak pada nama Nur atau An-Nur atas nama-nama bangunan-bangunan masjid yang dibangun oleh Jamaah Tabligh. Nama tersebut merupakan simbol "hadiah" dan "kenangan" yang ditujukan kepada peletak pertama pemikiran gerakan dakwah ini. ${ }^{19}$ Adapun versi ketiga mangatakan bahwa gerakan dakwah Jamaah Tabligh lahir sebagai upaya membendung gerakan Hinduisme Shuddi Sanghatan yang dilancarkan pada 1920an oleh Arya Samajists untuk memurtadkan umat Islam, khususnya di Mewat. Maulana Ilyas begitu teguh dan gigih dalam membendung gerakan Hinduisme ini. ${ }^{20}$

\section{Dakwah Jamaah Tabligh dari India ke Temboro}

Masuknya gerakan dakwah Jamaah Tabligh ke Temboro, Magetan tidak melalui Jemaah yang sudah lebih dahulu eksis di Indonesia, melainkan diperkenalkan secara langsung oleh Jemaah yang datang dari India di bawah pimpinan Amîr Ahmad Shabur, yaitu sekitar tahun 1980an. Ahmad Shabur sendiri adalah salah seorang cendekiawan dan guru besar di Universitas Alighard India. ${ }^{21}$ Di Temboro, Ahmad Shabur beserta Jemaah yang lain berdakwah dari pintu ke pintu rumah masyarakat. Mengajak dan memberi contoh konkrit kepada masyarakat untuk memakmurkan masjid, senantiasa salat berjemaah, membaca al-Qur'ân, menyampaikan hadîth-hadîth Nabi serta pengajaran adab-adab Islam sesuai petunjuk dari al-Qur'ân dan sunnah Nabi Muhammad. ${ }^{22}$

Suatu ketika Ahmad Shabur beserta Jemaah yang lain bersilaturrahim ke salah seorang tokoh masyarakat Temboro Magetan, yaitu Kiai Mahmud Khalid Umar atau yang akrab dikenal dengan Kiai Mahmud. Kiai Mahmud adalah generasi kedua penerus Pondok Pesantren Al-Fatah Temboro Magetan. Jamaah Tabligh sampai di Pesantren Al-Fatah ketika sudah masuk waktu salat zuhur. Setelah rombongan Ahmad Shabur memperkenalkan diri secara singkat kepada Kiai Mahmud, mereka kemudian bersama-sama melaksanakan salat berjemaah di belakang Kiai Mahmud. Selesai salat, Jamaah Tabligh memohon waktu menyempatkan silaturrahim secara khusus

\footnotetext{
19 Sayf al-Raḥmân Aḥmad, Naz̧rat 'Âbirah I'tibârîyah hawl al-Jamâ'ah al-Tablìgh (t.t.: Al-Madînah al-Munawwarah, t.th.), 4-5.

${ }^{20}$ An-Nadwi, Sejarah Mubammad Ilyas, 156.

${ }^{21}$ Munir, Pluralisme Madžbab, 139.

22 Ibid., 153.
} 
kepada Kiai Mahmud. Kiai Mahmud menyambutnya dengan hati terbuka.

Rombongan tersebut menyampaikan apapapun yang perlu disampaikan kepada Kiai Mahmud berkenaan dengan program dakwah yang mereka lakukan, khususnya tujuan mereka sampai di Temboro. Kiai Mahmud menyambut baik dengan konsep dan caracara berdakwah rombongan Jamaah Tabligh, bahkan ia secara pribadi berminat mengaplikasikannya. Secara khusus Kiai Mahmud menaruh simpati atas sikap dan kesederhanaan Ahmad Shabur beserta rombongan Jemaahnya. Hal ini ditunjang dengan pengalaman ibadahnya yang tidak biasa, khususnya dalam salat-salat berjemaah fardhu di mana baru kali ini Kiai Mahmud merasakan situasi pikiran dan hati yang jauh berbeda dari sebelumnya. Salat berjemaah bersama rombongan Jamaah Tabligh membawanya pada ketenangan jiwa, kedamaian hati serta sejuknya pikiran yang tidak dapat ia gambarkan.

Pengalaman mistis tersebut tidak hanya berhenti pada pengalaman Kiai Mahmud, kedatangan rombongan dakwah Jamaah Tabligh ke tempat Kiai Mahmud juga bersifat mistis. Ahmad Shabur mengatakan bahwa kedatangan Jamaah Tabligh ke tanah Temboro memang ditugaskan oleh Maulana In'amul Hasan, pemimpin tertinggi gerakan dakwah Jamaah Tabligh di India, padahal antara Maulana In'amul Hasan dan Kiai Mahmud tidak saling mengenal serta tidak pula pernah bertemu. $^{23}$

Kiai Mahmud sendiri, sebelum kedatangan Jamaah Tabligh ke Temboro, beberapa kali pernah bermimpi di mana di dalam mimpinya ia melihat bumi berubah menjadi hamparan lautan. Di tengah-tengah lautan terdapat perahu yang tengah berlayar dari Negeri India, yang ia ibaratkan sebagai perahu Nabi Nuh as. Dalam pandangan Kiai Mahmud, ketika menafsiri mimpinya, bahwa dunia ini sudah begitu banyak dipenuhi oleh kemaksiatan dan kerusakan, maka barang siapa yang berkenan berlayar bersama perahu tersebut ia akan selamat dari kerusakan dan kemaksiatan. ${ }^{24}$

Selain cerita mistis di atas, minat Kiai Mahmud kepada gerakan dakwah Jamaah Tabligh juga dikarenakan aliran tarekatnya. Jamaah Tabligh beraliran tarekat Naqshâbandîyah-Khâlidîyah di mana Kiai Mahmud sendiri adalah salah seorang murshid dalam tarekat tersebut. ${ }^{25}$

\footnotetext{
23 Ibid.

24 Ibid., 155.

25 Ibid., 151 dan 156.
} 
Dengan demikian di antara keduanya sudah ada "keterpautan emosional" secara amalan.

Alasan kemantapan Kiai Mahmud menerima model gerakan dakwah yang diusung oleh Jamaah Tabligh juga karena model dakwah Jamaah Tabligh memiliki kesamaan dengan model dakwah $W$ alisongo, terutama Sunan Kalijaga, yaitu model dakwah kburîj empat bulan. Yen kali ilang kedunge, yen pasar ilang kemandange, yen wong wadon ilang wirange, enggal-enggal topo lelono njajah deso milangkori ojo bali sak durunge patang sasi, entuk wisik soko byang widi (Allah). ${ }^{26}$ (Apabila sungai sudah mengering, pasar sudah hilang gaungnya, perempuan sudah hilang malunya, maka segeralah bertapa (mendekatkan diri kepada Allah) dari desa ke desa, jangan pulang sebelum sampai empat bulan, (maka) nanti akan memperoleh ilham dari Allah).

Sebagai seorang pengikut Nahdlatul Ulama (NU) [bahkan Kiai Mahmud adalah salah satu tokoh penting dalam NU di mana dia merupakan salah seorang anggota Syuriyah PCNU Kabupaten Magetan dan sebagai A'wân (Pembantu Umum) di struktural PWNU Jawa Timur], maka model dakwah Jamaah Tabligh pada dasarnya bukanlah hal baru dalam tradisi NU. Hal ini karena jargon model dakwah NU adalah sebagai pewaris dari usaha dakwah Walisanga. ${ }^{27}$

Wasiat dakwah yang disampaikan oleh Sunan Kalijogo di atas menjadi pendukung argumentasi atas penerimaan model gerakan dakwah Jamaah Tabligh di Temboro Magetan bagi Kiai Mahmud. ${ }^{28}$ Alasan di atas juga menekankan agar seruan dakwah mudah diterima oleh masyarakat, terutama masyarakat tradisional yang masih awam, serta sebagai antisipasi kemungkinan munculnya tuduhan dan fitnah atas model dakwah Jamaah Tabligh yang belum akrab di tengahtengah masyarakat.

Momentum kehadiran model gerakan dakwah Jamaah Tabligh juga memiliki nilai tersendiri bagi Kiai Mahmud. Hal ini karena sekembalinya NU ke Khittah 1926 pada tahun 1984 pada Muktamar NU di Situbondo, ${ }^{29}$ Kiai Mahmud masih belum menemukan pola dakwah yang tepat untuk diimplementasikan di tengah-tengah

\footnotetext{
26 Pesantren Al-Fatah Temboro, Mudzakarah Dakwah Usaha Rasulullah SAW (Magetan: Maktabah Al-Barakah, 2012), 74.

${ }^{27}$ Lihat A. Khoirun, Meneruskan Tradisi Dakwah Para Pendabulu, dalam www.nu.or.id diakses 17 Oktober 2016; Zudi Setiawan, Nasionalisme NU (t.t.: Aneka Ilmu, 2007), 220.

${ }^{28}$ Temboro, Mudzakarah Dakwah, 75.

${ }^{29}$ Hamzah, Khittah NU, dalam www.nu.or.id diakses 17 Oktober 2016.
} 
masyarakat. Dengan demikian kehadiran model dakwah Jamaah Tabligh menjawab sekaligus mengobati kerisauan Kiai Mahmud. ${ }^{30}$

Untuk lebih memantapkan hati atas model dakwah yang di pilihnya, di samping selalu meminta petunjuk dari Allah, Kiai Mahmud bersama putra tertuanya, Uzairon Thoifur Abdullah, merasa sangat perlu berkunjung ke markaz Jamaah Tabligh India, yaitu di Nidzamuddin untuk mengetahui lebih dekat dan seksama kehidupan dan eksistensi Jamaah Tabligh. Kehidupan dalam kesederhanaan serta akhlak mulia para mashâyikh Jamaah Tabligh dan para anggota Jemaah di Nidzamuddin benar-benar semakin membawa minat yang dalam bagi Kiai Mahmud untuk berdakwah dengan model dakwah Jamaah Tabligh. ${ }^{31}$ Bergabungnya Kiai Mahmud ke dalam gerakan dakwah Jamaah Tabligh di dukung kharisma ke-kiai-annya secara moral akan memudahkan dakwah ini diterima oleh masyarakat. Bersama putranya, Uzairon, Kiai Mahmud menjadi lokomutif gerakan perubahan bagi masyarakat Temboro menuju masyarakat yang religius melalui model dakwah Jamaah Tabligh.

\section{Ikrâm al-Muslim Perspektif Jamaah Tabligh}

Setiap gerakan dakwah mempunyai konsep masing-masing sebagai pijakan dalam menjalankan program-program dakwahnya, demikian juga yang terdapat pada gerakan dakwah Jamaah Tabligh. Salah satu konsep utama gerakan dakwah Jamaah Tabligh adalah ikrâm al-Muslim. Konsep ikrâm al-Muslim merupakan pintu yang melapangkan jalan kemudahan gerakan dakwah ini masuk ke dalam komunitas berbagai aliran pemahaman dan kelompok-kelompok sosial Muslim lainnya. ${ }^{32}$

Ikrâm al-Muslim sebagaimana penjelasan sebelumnya merupakan ajaran yang sudah dicontohkan oleh Rasulullah dan dipraktikkan secara sungguh-sungguh oleh para sahabatnya. Karena merupakan ajaran, maka pada umumnya setiap kelompok aliran pemahaman dalam Islam memegang makna yang terkandung di dalam ikrâm alMuslim. Namun setiap kelompok gerakan dakwah mempunyai persepsi pemaknaan masing-masing yang berbeda terkait bentuk

\footnotetext{
${ }^{30}$ Munir, Pluralisme Madžhab, 154.

${ }^{31}$ Ibid., 156.

32 Sebagai rujukan lengkap Jamaah Tabligh atas dalil-dalil prinsp ikrâm Al-Muslim adalah buku yang ditulis oleh Maulana Muhammad Yusuf al-Kandahlawi yang disusun kembali oleh Maulana Muhammad Sa'ad al-Kandahlawi. Lihat Maulana Muhammad Yusuf al-Kandahlawi, Muntakhab Aḥâdîth: Dalil-dalil Piliban Enam Sifat, terj. Ahmad Nur Khalis al-Adib dan Mujahid (Yogyakarta: Ash-Shaff, Cet ke-2, 2007), 402, 536.
} 
aplikasinya. Ada yang memahami bahwa ikrâm al-Muslim hanya berlaku untuk komunitas Muslim atau orang-orang Muslim di mana corak pemikiran keagamaan, 'amalîyah, dan kecenderungan pemahaman keagamaannya sama. Maka kelompok yang berada di luar garis corak pemahaman mereka bukan termasuk golongan mereka. Artinya, mereka tidak mendapatkan hak yang pantas diperlakukan sebagai ikrâm al-Muslim. Kelompok ini di kenal dengan almutashaddidûn fì al-dìn, yaitu kelompok yang keras dalam beragama. ${ }^{33}$

Jamaah Tabligh melihat bahwa ikrâm al-Muslim adalah ajaran agama yang harus ditanamkan ke tengah-tengah masyarakat luas. Seseorang yang sudah ber-Islam maka orang tersebut adalah saudara dan harus diperlakukan secara terhormat. Sikap terhadap sesama Muslim harus lebih mendahulukan perasaan dan pikiran yang positif daripada menaruh perasaan curiga dan berpikir secara negatif. Maka hal-hal yang mengarah kepada terbukanya emosi, tersinggung, dan curiga harus dihindari, diantaranya adalah dengan tidak mempermasalahkan latar belakang maupun status sosial Muslim di tengah-tengah masyarakat. Selama ia seorang Muslim, maka ia harus diperlakukan secara mulia. Bagi Jamaah Tabligh, seluruh kaum Muslimin di dunia ini adalah saudara yang harus dimuliakan, tidak peduli apapun pilihan politik, status sosial, jabatan, aliran pemahaman keagamaan, 'amalìyah, dan lain sebagainya. Ikrâm al-Muslim adalah salah satu sifat yang paling menunjol dari para al-salaf al-sâlih, yaitu para sahabat Nabi dan orangorang yang mengikuti jalan hidup mereka. Sifat penting ini terangkum dalam enam sifat sahabat, ${ }^{34}$ yaitu sifat al-sittah (enam sifat) yang menjadi prinsip gerakan dakwah Jamaah Tabligh. ${ }^{35}$

\footnotetext{
33 Pada konteks ini, orang-orang yang berada di luar garis kelompok mereka adalah orang-orang yang masih belum sempurna menjalankan perintah agamanya, atau kelompok di luar garis ini adalah sekumpulan orang-orang yang tersesat (dalâ), orang-orang yang menyimpang (bid'ah), atau orang-orang yang mencari alternatif di luar garis-garis yang sudah ada di dalam sharíah (mushrik). Kelompok ini mempopulerkan diri sebagai gerakan salaf, yaitu suatu kelompok yang mentahbiskan diri sebagai pengembali kemurnian ajaran Islam, memerangi kemusyrikan, khurafât, bid'ah, dan takhayyulât. Lihat 'Alî Jum'ah, al-Mutshaddidûn: Manhajubum wa Munâqashat Ahamm Qadâyâhum (Kairo: Dâr al-Maqtam li al-Nashr wa al-Tawzî', 2012), 5-7.

${ }^{34}$ Enam sifat tersebut adalah: aktualisasi kalimat tayyibah (lâ ilâha illâ Allâh), salat

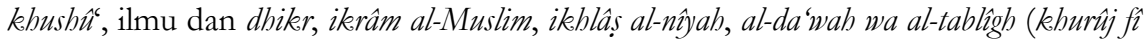
sabîl Allâh). Lihat Maulana Asyiq Ilahi, Enam Sifat Sababat R.A (Yogyakarta: AshShaff, 1995), 25.

35 Yayasan Pendidikan Al-Fatah, Enam Sifat Doa Hidayah (Magetan: Yayasan Pendidikan Al-Fatah, t.th.), 1-8.
} 
Ikrâm al-Muslim adalah menunaikan hak-hak sesama Muslim tanpa ada pamrih apapun. Menurut pandangan Jamaah Tabligh, ukuran paling rendah ikeâm al-Muslim adalah bersabar dan tidak merepotkan orang lain. Menyusahkan orang lain akan berdampak kepada rusaknya amalan. Suatu amal tidak akan sempurna tanpa disertai dengan ikrâm. Ikram tidak hanya terbatas kepada lisan, tetapi ia harus pula dengan hati nurani serta perbuatan. ${ }^{36}$

Ikram al-Muslim tidak memandang dan dibatasi oleh status, kelompok, atau golongan. Ikrâm al-Muslim meliputi seluruh umat Islam, yang miskin, yang kaya, alim, pejabat atau bahkan rakyat jelata. Ikrâm adalah kepada semua mereka yang sudah memiliki kalimat lâ ilâha illa Allâh. ${ }^{37}$ Ini berarti berlaku juga bagi para pendosa (yang belum sadar dari kemaksiatan) sekalipun ${ }^{38}$ di mana sebagai Muslim mereka berhak mendapatkan ikrâm. ${ }^{39}$ Kemudian ikrâm al-Muslim yang paling tinggi adalah mengajak orang lain taat kepada Allah agar selamat dari azab-Nya di dunia dan di akhirat. ${ }^{40}$

Maulana Ilyas sebagai peletak utama pemikiran gerakan dakwah ini memandang bahwa kehadiran Jamaah Tabligh tiada lain kecuali untuk memuliakan umat Islam dan melayani meraka, bahkan apabila perinsip ikrâm ini diabaikan maka akan timbul berbagai kesulitan dan keburukan yang akan menimpa perjuangan Jamaah Tabligh. ${ }^{41}$ Dalam kesempatan yang lain Maulana Ilyas mengatakan bahwa kemaksiatan yang paling besar dan merupakan puncak dari ribuan maksiat-yang menyebabkan menjauhnya orang Islam dari orang Islam lainnya sesama saudara akidah sehingga melunturkan keutamaan kerja-kerja

\footnotetext{
36 An-Nadhr M. Ishaq Shahab, Khuruj Fi Sabilillab: Sarana Tarbiyah Umat untuk Membentuk Sifat Imaniyah (Bandung: Pustaka Al-Ishlah, t.th.), 108-109.

${ }^{37}$ Ibid., 109.

38 Banyak mantan orang-orang “tersesat" yang akhirnya kembali ke pangkuan Iman, semisal anak-anak punk, preman-preman besar, dan mantan-mantan rocker, bahkan mereka menjadi pendakwah, di antara mereka adalah Derry Sulaiman (mantan gitaris Rock Batrayer), Salman, yang dikenal dengan nama Sakti (mantan gitaris Sheila on 7), Budi Santoso (mantan preman kelas kakap), dll. Kesaksian penulis ketika mengikuti pengajian umum yang digelar oleh Jamaah Tabligh dalam tema "Ngopi" (Ngobrol Perkara Iman), di Magetan, Ahad 18 September 2016 di Masjid alHidayah Jl. Tripandita Magetan.

${ }^{39}$ An-Nadwi, Sejarah Mubammad Ilyas, 185.

${ }^{40}$ Shahab, Khuruj Fi Sabilillah, 159, 168.

41 An-Nadwi, Sejarah Mubammad Ilyas, 185.
} 
jamâ'ah (kolektif) dan melenyapkan kekuatannya pada zaman iniadalah karena hilangnya penghormatan (ikrâm) sesama Muslim. ${ }^{42}$

Secara umum, prinsip ikrâm tidak hanya berhenti kepada sesama Muslim, bahkan mencakup kepada nilai-nilai kemanusian seluruhnya. Lebih jauh Maulana Ilyas menegaskan bahwa kasih sayang, memaafkan, saling menghormati satu sama lain adalah lebih berharga dari pada apapun. Memperhatikan amalan nilai-nilai kemanusiaan kemudian istiqâmah memperjuangkannya adalah lebih tinggi dan lebih pasti untuk memperoleh ridha dari Allah daripada mematuhi seribu prinsip sharî́ah tetapi melecehkan nilai-nilai kemanusiaan. ${ }^{43}$ Atas prinsip menjaga dan menghormati nilai-nilai kemanusiaan, dengan akhlak dan cinta damai, maka banyak pada akhirnya orang-orang nonMuslim yang berada di luar Islam manaruh simpati atas dakwah Jamaah Tabligh hingga kemudian mereka tertarik dan banyak yang masuk ke dalam agama Islam. ${ }^{44}$

\section{Aktualisasi ikrâm}

Sebagaimana penjelasan sebelumnya bahwa ikrâm al-Muslim tidak hanya terbatas pada aksi hati dan lisan saja, tetapi ikrâm al-Muslim harus benar-benar mewujud kepada aksi perbuatan yang konkret. Aksi aplikatifnya bisa berupa dengan menunaikan hak-hak sesama Muslim tanpa ada pamrih apapun.

a. Hak Muslim dalam harta

Jamaah Tabligh dalam dakwahnya menekankan kepada para kaum Muslimin, khususnya kepada setiap anggota Jemaah yang diberi kelebihan harta supaya cinta berbagi untuk mereka yang kekurangan. Mereka meyakini bahwa siapa saja yang memenuhi

\footnotetext{
42 Ibid., 184.

${ }^{43}$ Ibid., 160.

44 Pada tahun 1973 diadakan ijtimâ' akbar (pertemuan akbar) Jamaah Tabligh di Shelfield, Inggris. Pertemuan tersebut dihadiri 10.000 Jemaah dari 28 negara. Acara digelar selama tiga hari berturut-turut. Pada acara ini banyak orang-orang nonMuslim yang menaruh kesan positif dan merasa tersentuh dengan pamandangan yang mereka saksikan. Polisi-polisi yang mengawasi jalannya acara merasa takjub, sampai ada yang mengatakan: "sungguh bahwa inilah agama yang benar." Sebab belum pernah mereka menyaksikan perkumpulan ribuan orang yang berjalan dengan tenang dan tertib. Tidak ada keributan sedikitpun, tidak ada pencurian, apalagi perkelahian. Satu sama lain saling menghormati, serta mendahulukan kepentingan orang lain. Pada akhirnya banyak orang non-Muslim yang memeluk Islam setelah menyaksikan acara tersebut, baik dari polisi, seorang jurnalis yang ikut meliput acara, hingga pendeta. Lihat As-Sirbuni, Kupas Tuntas Jamaah Tabligh, Vol. 1, 140-141.
} 
kebutuhan saudaranya, maka ia akan dipenuhi hajat kebutuhannya oleh Allah dan siapa saja yang bisa memberi kelonggaran kepada saudaranya yang Muslim tentang urusan harta benda di dunia, maka ia akan dianugerahi kelonggaran dari berbagai kesulitan kelak di hari kiamat. Atau siapa saja yang memudahkan urusan saudara sesama Muslim dari kesukaran dunai maka Allah pasti akan memberikan kemudahan kepadanya. ${ }^{45}$ Seorang Muslim yang pandai membelanjakan hartanya (bersedekah) ia terhindar dari bencana, dijauhkan dari penyakit, jauh dari kehinaan, dan terhindar dari murka Allah. ${ }^{46}$ Dengan demikian seorang Muslim yang ingin memperoleh anugerah dari Allah di atas maka ia tidak bisa tidak harus mempunyai kelimpahan harta kemudian membantu mereka yang memang membutuhkannya.

Berdasarkan atas prinsip di atas, tidak beralasan jika dikatakan bahwa anggota Jamaah Tabligh adalah komonitas pemalas, meninggalkan urusan duniawi dan tidak bekerja, serta gemar bepergian (khurîj) yang sia-sia. Jamaah Tabligh melakukan khurîj hanya sepersepuluh dari setahun, yaitu hanya 40 hari, sepersepuluh dari setiap bulan, yaitu hanya 3 hari, kemudian sepersepuluh dari satu hari (24 jam), yaitu hanya dua setengah jam setiap hari. Selebihnya mereka sibuk dengan urusan-urusan yang besifat duniawi. ${ }^{47}$

b. Hak Muslim pada diri

Hak seorang Muslim pada diri kita adalah dengan memberikan bantuan atas apa yang dibutuhkannya, baik itu diminta ataupun tidak diminta. Menjenguknya apabila mereka sakit atau tertimpa musibah, atau membantu meringankan pekerjaannya jika mereka sibuk. Nilai yang paling tinggi adalah membantunya dengan jiwa dan raga dalam sesuatu hal yang dapat membahayakan dirinya. ${ }^{48}$ Lebih lanjut, hak-hak Muslim kepada diri ada enam hak sebagaimana yang terdapat dalam sabda Nabi yaitu: mengucapkan salam apabila bertemu, memenuhi undangannya apabila ia mengundang, mengucapkan yarḅamuk Allâh (semoga Allah merahmatimu) apabila ia bersin, menengoknya jika ia sakit,

\footnotetext{
45 Shahab, Khuruj Fi Sabilillah, 110.

46 Maulana Muhammad Zakariya al-Kandahlawi, Fadhilah Sedekah, terj. Supriyono Abdullah (Yogyakarta: Ash-Shaff, t.th), 104.

${ }^{47}$ As-Sirbuni, Kupas Tuntas Jamaah Tabligh, Vol. 1, 75.

${ }^{48}$ Shahab, Khuruj Fi Sabilillah, 110.
} 
mengantarkan janazahnya apabila ia meninggal dunia, dan merasa senang apabila ia mendapatkan apa yang menjadi hajat dan kebutuhannya. ${ }^{49}$

c. Hak Muslim pada lisan

Hak seorang Muslim pada lisan adalah bisa berupa bentuk kalimat atau kata-kata yang benar, artinya menempatkan kata-kata sesuai kondisi dan situasinya, ${ }^{50}$ memanggilnya dengan sebutan yang disukainya, mengingatkan ketika ia lalai, menyampaikan pesan orang lain yang di alamatkan kepadanya, berdoa untuk kebaikan dirinya dan keluarganya, baik yang menyangkut perkara kehidupan ataupun kematiannya, baik ketika saudara kita Muslim berada bersama atau sedang tidak bersama kita. ${ }^{51}$

d. Hak Muslim dalam hati

Hak seorang Muslim dalam hati adalah dengan senantiasa berbaik sangka kepadanya (ḅusn al-zann). Setiap hati seorang Muslim hendaknya menyadari dan memahami bahwa manusia bukanlah malaikat yang tidak bisa salah. Seorang Muslim bukanlah manusia ma'ŝum (manusia suci, bersih dari kesalahan dan dosa). ${ }^{52}$ Menyadari bahwa tidak ada orang yang terbebas dari kesalahan akan memudahkan hati untuk segera memafhumi atas kekeliruan yang sedang menimpa saudaranya, melapangkan pikiran untuk segera berpikir positif tentangnya, dan memudahkan hati untuk memberikan maaf kepadanya. Seorang Muslim senantiasa berharap kebaikan bagi saudara Muslim lainnya, sebagaimana ia sendiri mengharapkan kebaikan. ${ }^{53}$ Doa-doa kebaikan seorang Muslim terhadap Muslim yang yang lain tanpa sepengetahuannya akan diijâbah oleh Allah, sebagaimana ia (yang berdoa) akan dikabulkan keinginannya oleh Allah. ${ }^{54}$

e. Hak Muslim dalam hal mencintai yang bermanfaat dan membenci hal yang mudârât baginya. Sepantasnya seorang Muslim mendatangkan sesuatu yang bermanfaat untuk saudara Muslim

\footnotetext{
49 Al-Kandahlawi, Muntakhab Abâdîth, 432.

${ }^{50}$ Muhammad Nâsib al-Rifấî, Taysîr al-'Alì al-Qadîr: Ikhtị̂âr Tafsîr Ibn Kathîr (Riyậ: Maktabah al-Ma'ârif, 1989), 450.

${ }^{51}$ Shahab, Khuruj Fi Sabilillah, 110.

52 Ibid.

53 Ali Abdul Halim Mahmud, Dakwah Fardiyah: Membentuk Pribadi Muslim, terj. As'ad Yasin (Jakarta: Gema Insani Press, Cet. 2, 2004), 96.

${ }^{54}$ Al-Kandahlawi, Muntakhab Aḅâdîth, 448.
} 
lainnya sehingga ia merasa gembira dengan sesuatu tersebut. Demikian pula selayaknya seorang Muslim membenci sesuatu yang mendatangkan mudârât baginya dan berusaha untuk mencegahnya. Jamaah Tabligh mendasarkan ajaran ini pada sabda Nabi yang menegaskan bahwa umat Islam diibaratkan seperti satu tubuh di mana jika salah satu organ tubuh merasakan sakit, maka seluruh organ-organ tubuh lainnya juga merasakan sakit. ${ }^{55}$

\section{Membangun Masyarakat Religius di Temboro}

Secara umum, setiap manusia menginginkan kondisi kehidupan yang sejahtera. Sebab itu manusia selalu berusaha dan mencari cara untuk mewujudkannya, walaupun manusia tidak akan pernah sampai kepada kesejahteraan yang sesungguhnya. Oleh karena itu, kondisi kesejahteraan yang diidealkan oleh manusia tidak akan pernah hadir sepenuhnya, maka dengan demikian, upaya melakukan perubahan menuju kondisi ideal akan terus berlangsung sepanjang waktu. Proses untuk sampai kepada kondisi kehidupan yang lebih baik tersebut dalam ilmu sosial biasa dikenal dengan istilah pembangunan masyarakat. ${ }^{56}$ Proses tersebut menunjukkan bahwa masyarakat tidak bersifat statis, tidak mandeg, dan tidak bersifat monolitik, masyarakat selalu bergerak dan berubah, dinamis, dan heterogen. ${ }^{57}$

Sebagian banyak orang mengidam-idamkan bahwa kesejahteraan hidup dapat tercapai melalui hidup secara religius, karena religiositas membangun optimisme yang tinggi dalam diri manusia. ${ }^{58}$ Sikap optimis akan membawa kepada kesuksesan, kebahagian, dan kesejahteraan. ${ }^{59}$ Ciri masyarakat religius adalah masyarakat yeng berketuhanan, baik berbentuk agama yang terlembaga, kerpercayaan kolektif maupun kepercayaan perorangan. ${ }^{60}$ Dengan kata lain, religius adalah keimanan (faith), yaitu pengalaman batin pribadi tentang yang ilahi tentang cara pribadi merasakan dan menghayati yang "tak

\footnotetext{
55 Al-Hafiz Aḥmad b. 'Alî b. Hajr al-'Asqalânî, Fatḥ al-Bârî bi Sharḥ Ṣahîh al-Bukhârî, Vol. 10, "Kitâb al-Adab”, Hadîth 6011 (Beirut: Dâr al-Ma'rifah, t.th.), 438.

${ }^{56}$ Soetomo, Pembangunan Masyarakat: Merangkai sebuah Kerangka (Yogyakarta: Pustaka Pelajar, Cet. 2, 2012), v.

${ }^{57}$ Syarifuddin Jurdi, Sosiologi Islam: Elaborasi Pemikiran Sosial Ibn Khaldun (Yogyakarta: Teras, 2008), 68.

58 Ibid., 206.

59 Koko Liem, The Power Husnuz Zan: Berbaik Sangkalah Maka Hidupmu Akan Barokah (Jakarta: Penebar Swadaya Group, 2012), 65.

${ }^{60}$ Tim Ditjenbud, Strategi Pembinaan dan Pengembangan Kebudayaan Indonesia (Jakarta: Direktorat Jenderal Kebudayaan, 2000), 40.
} 
tampak". ${ }^{11}$ Oleh karena itu dalam Islam religius bisa digambarkan sebagai orang yang beragama, percaya dengan kebenaran agamanya, dan tekun mengamalkan ajaran-ajaran agamanya, baik yang berupa ibadah wajib ataupun yang bersifat ibadah sunnah. Dengan pengamalan yang terus menerus (istiqâmah) dimungkinkan dapat melahirkan karakter religius yang teraplikasikan dalam kehidupan nyata sehari-hari.

Jiwa pribadi yang beragama dengan baik dan benar senantiasa merasakan adanya kehadiran Dzat "yang tak tampak" dalam dirinya, yaitu Allah. Individu seperti ini selalu merasa bahwa segala gerakgeriknya, sikap dan prilakunya selalu diawasi oleh Tuhan. Oleh karena itu ia memahami apabila melakukan perbuatan yang melanggar ajaranajaran agamanya, maka hal itu akan mendatangkan murka dan azabNya. Pribadi yang demikian akan senantiasa berperilaku seperti apa yang disukai oleh Tuhan dan bersikap sesuai dengan petunjukpetunjuk-Nya.

Pribadi seperti di atas akan menjelma menjadi pribadi yang religius di tengah-tengah masyarakat, yaitu pribadi yang tidak hanya menjaga hubungan vertikal dengan Tuhannya, tetapi juga memperhatiakn hubungan horizontal, yaitu hubungan antar sesama manusia. Ia menjadi pribadi yang berbudi luhur, jujur, sopan-santun, rukun, hormat, suka menolong, dan tenggang rasa. ${ }^{62}$ Menjaga hubungan secara positif yang bersifat horizontal antar sesama manusia inilah yang membentuk tatanan masyarakat religius, atau dengan ungkapan yag lain, bahwa masyarakat religius adalah masyarakat yang mengamalkan secara konsisten nilai-nilai agama atau kepercayaannya.

Penjelasan di atas menandaskan bahwa religiositas berfungsi mengatur sikap-sikap dan pola-pola kelakuan dan hubungan lahir dan batin terhadap yang vertikal (habl min Allâh) dan terhadap yang horizontal (habl min al-nâs). ${ }^{63}$ Menjadi religius berarti menjalani (atau, mencoba menjalani) kehidupan moral di dunia sosial yang heterogen dan menjadi religius berarti menjalani kehidupan yang bertanggungjawab. Menjadi tidak bertanggungjawab berarti tidak religius. $^{64}$

61 I. Bambang Sugiharto dan Agus Rachmat W. Wajah Baru Etika dan Agama (Yogyakarta: Penerbit Kanisius, Cet. 5, 2004), 150.

62 Tim Ditjenbud, Strategi Pembinaan dan Pengembangan, 40.

${ }^{63}$ Hendropuspito, Sosiologi Agama (Yogyakarta: Kanisius, Cet. 22, 2006), 113.

${ }^{64}$ Paul F. Knitter, Satu Bumi Banyak Agama: Dialog Multi-Agama dan Tanggung Jawab Global (Jakarta: Gunung Mulia, 2008), 152. 
Dalam perspektif proses pembangunan masyarakat di mana manusia menjadi faktor dan sekaligus sebagai aktor utama perubahan, ${ }^{65}$ perilaku religiositas dapat menjadi salah satu (untuk tidak mengatakan satu-satunya) sumber daya pembangunan masyarakat yang pokok. Artinya, religiositas merupakan unsur kemanusian yang utama. Sikap optimisme religius atas kehidupan serta prilaku-perilaku al-akblâq al-karimah merupakan modal besar menuju masyarakat yang sejahtera dan sekaligus bahagia.

Religiositas yang diidealkan sebagaimana penjelasan di atas juga berlaku bagi masyarakat Temboro, tempat di mana Pesantren AlFatah yang merupakan salah satu markaz utama Jamaah Tabligh Indonesia berada. Dari letak geografis, Temboro merupakan desa yang berjarak $12 \mathrm{~km}$ dari pusat kota Kabupaten Magetan. Luas wilayah desa ini $\pm 517.322 \mathrm{ha}{ }^{66}$ Warga penduduk Temboro mayoritas berasal dari etnis Jawa dan Betawi dengan total penduduk berjumlah sekitar 6.446 orang. Dilihat dari segi mata pencaharian, masyarakat Temboro memiliki beragam profesi, seperti pedagang, wiraswasta, pegawai, guru, dan birokrat. Namun seperti umumnya masyarakat pedesaan, sebagian besar mata pencaharian warga masyarakatnya adalah bertani, baik yang menggarap lahannya sendiri ataupun yang bertani dengan bekerja kepada orang lain (buruh tani). ${ }^{67}$

Selanjutnya, aspek pendidikan di Temboro juga cukup maju. Hal ini, antara lain, bisa dilihat dari sejumlah lembaga pendidikan yang terdapat di sana, baik yang formal ataupun yang non-formal. Lembaga pendidikan formal tingkat TK/RA ada lima lembaga, setingkat SD ada empat lembaga, setingkat SMP ada tiga lembaga, dan setingkat SMA ada dua lembaga. Adapun lembaga pendidikan non-formal yang terdapat di Temboro adalah pondok pesantren ada empat lembaga, pendidikan TPQ ada lima lembaga, dan madrasah diniyah ada sembilan lembaga. ${ }^{68}$ Tingkat serta jumlah kemajuan pendidikan yang demikian membuka peluang berkembangnya wawasan yang luas dan dengan keluasan wawasan tersebut maka sangat memungkinkan mendorong masyarakat Temboro untuk menciptakan dan menjaga kerukunan serta bangunan sosial yang sangat positif.

\footnotetext{
${ }^{65}$ Soetomo, Pembangunan Masyarakat, 193.

${ }^{66}$ Munir, Pluralisme Madzhab, 109.

${ }^{67}$ Ibid., 110.

${ }^{68}$ Ibid., 111-112.
} 
Terkait dengan keanggotaan organisasi kegamaan, masyarakat Temboro terbagi menjadi dua organisasi besar, NU, yang menjadi kelompok mayoritas di Temboro, dan sebagian Muhammadiyah (MU). Meskipun demikian terdapat perkembangan terbaru di mana ada kecenderungan beberapa anggota masyarakat di desa ini yang mengikuti paham Wahabi. ${ }^{69}$

Jauh sebelum Jamaah Tabligh hadir di Temboro, kehidupan warga masyarakat Temboro tidak berbeda jauh dari desa-desa tetangga lainnya. Kehidupan beragama belum tampak semarak sebagaimana saat sekarang ini. Sebagai contoh, saat ini apabila ada laki-laki ingin bertamu ke suatu rumah dan kebetulan di rumah tersebut yang ada hanya seorang wanita, warga masyarakat Temboro tidak akan membukakan pintu untuk tamu itu. Hal semacam ini sudah menjadi kebiasaan warga masyarakat Temboro. ${ }^{70}$ Sesuatu yang, mungkin, mengagumkan adalah ketika terdengar suara azan, warga masyarakat Temboro akan meninggalkan apapun pekerjaannya, mulai dari yang berdagang, mereka akan berhenti bertransaksi atas dagangannya, yang sebelumnya di sawah akan segera kembali pulang. Mereka berduyunduyun memenuhi masjid dan musala untuk menunaikan salat berjemaah tanpa terkecuali. ${ }^{71}$

Tidak hanya dari sisi religiositas kehidupan warga masyarakat Temboro berubah, kehadiran Jamaah Tabligh juga telah merubah kehidupan ekonomi warga masyarakat Temboro. Ekonomi masyarakat Temboro sebelum kedatangan Jama'ah Tabligh berada di bawah rata-rata dari desa-desa lainnya, mereka berkehidupan sangat minim. Namun saat ini mereka tidak ada yang berkekurangan dalam mencukupi kebutuhan hidup sehari-hari setelah hadirnya Jama'ah Tabligh. Seiring dengan berdatangannya para pendakwah, para santri yang ingin menimba ilmu di sana dari berbagai belahan daerah di Indonesia, bahkan dari manca negara, benar-benar telah mendatangkan berkah dan keuntungan tersendiri bagi warga masyarakat Temboro. Kedatangan mereka dimanfaatkan oleh penduduk sekitar untuk mendatangkan keuntungan ekonomi, yaitu dengan berdagang atau menyediakan jasa transportasi. Masyarakat Temboro banyak yang menyediakan pakaian, menjual baju, serta

\footnotetext{
${ }^{69}$ Ibid., 12.

${ }^{70}$ Rowi Dalhari, Sejarah Masuk dan Perkembangan Jamaab Tabligh di Temboro Magetan (Surabaya: UINSA, 2014), 50.

${ }^{71}$ Ibid., 51.
} 
perlengkapan sekolah dan kitab-kitab yang dibutuhkan. Apapun yang dijual di sini pasti dibutuhkan oleh para pendakwah dan para santri yang datang. ${ }^{72}$

Sebagaimana telah disebut di atas bahwa lokomutif penggerak dakwah Jamaah Tabligh di Temboro adalah Kiai Mahmud dibantu oleh anaknya, Uzairon. Model dakwah ala Jamaah Tabligh yang diimplementasikan ketengah-tengah masyarakat saat itu tidak serta merta bisa diterima oleh masyarakat Temboro. Masyarakat Temboro, pada awalnya, justru merasa asing dan bahkan aneh dengan gaya dakwah Kiai Mahmud. Hal ini karena model dakwah Jamaah Tabligh yang dinilai sangat jauh berbeda dari model dakwah yang sudah umum ada.

Perbedaan, terasa asing atau ketidakbiasaan model dakwah itu tampak pada waktu pelaksanaan dakwah. Misalnya, seorang Muslim sebaiknya menyisihkan sepersepuluh waktunya untuk bisa berpikir dan beramal agama (dakwah sekaligus belajar agama) ${ }^{73}$ memilih waktu yang paling memungkinkan bisa untuk keluar (khurîj) berdakwah, ${ }^{74}$ sepersepuluh dari setiap tahun adalah 40 hari, sepersepuluh dari setiap bulan adalah tiga hari, dan sepersepuluh dari 24 jam setiap harinya adalah 2,5 jam. $^{75}$ Ketidakbiasaan model dakwah lainnya adalah berdakwah secara berjemaah. ${ }^{76}$ Dakwah berjalan kaki dari sudut kampung ke kampung yang lain secara berjemaah merupakan sesuatu yang janggal menurut pandangan umum dan, sampai batas tertentu, mengundang kecurigaan. Tidak hanya berkelompok, tetapi mereka juga rajin ghast (mendatangi orang dari rumah ke rumah), ke pasar-

\footnotetext{
72 Ibid., 49-50.

${ }^{73}$ Atau bisa dibalik, yaitu belajar agama sekaligus berdakwah, sebab Jamaah Tabligh adalah madrasah atau "sekolah bergerak" di mana orang-orang yang awam agama sekalipun bisa langsung ikut khurîj fî̀ sabîl Allâh. Didalamnya mereka belajar bersungguh-sungguh tentang agama, kemudian apabila dirasa memungkinkan mereka bisa menyampaikannya (tabligh). Jadi, amal khurûj adalah wadah setiap Muslim untuk menjadi 'âlim, 'âmil, dan sekaligus dầî. Lihat As-Sirbuni, Kupas Tuntas Jamaah Tabligh, Vol. 1, 88.

${ }^{74}$ Waktu-waktu tersebut bukanlah waktu yang paten yang harus genap bilangannya demikian, waktu-waktu itu hanya wasilah saja. Artinya, berdakwah bisa lebih lama atau lebih pendek dari bilangan waktu tersebut sesuai dengan keadaan dan kondisi. Bilangan itu hanya untuk lebih menekankan supaya kaum Muslimin benar-benar menyisihkan waktu secara khusus demi agamanya. Lihat Abdurrahman Ahmad AsSirbuni, Kupas Tuntas Jamaah Tabligh, Vol. 2 (Cirebon: Pustaka Nabawi, Cet. 3, 2010), 17.

75 As-Sirbuni, Kupas Tuntas Jamaah Tabligh, Vol. 1, 75.

${ }^{76}$ Ibid., Vol. 2, 160-77.
} 
pasar, bersilturahim untuk mengajak orang lain salat berjemaah ketika sudah masuk waktu salat ke masjid atau musala serta mengajak menghidupkan amalan-amalan sunnah. ${ }^{77}$

Penampilan fisik Jamaah Tabligh juga tidak seperti kebanyakan masyarakat kala itu. Mereka rata-rata gemar memelihara jenggot, berbaju sampai ke lutut, bercelana cingkrang di atas mata kaki (jjbâl) atau memakai jubah. Markaz mereka ketika berdakwah adalah di masjid-masjid atau di musala-musala, ${ }^{78}$ beserta hal-hal lain yang tidak umum berlaku bagi para pendakwah, semisal membawa perabotan dapur sebagai peralatan memasak serta bahan-bahan makanan yang dibutuhkan sebagai bekal selama khurûj fì sabîl Allâh.

Selain karena ketidaktahuan warga masyarakat secara umum tentang dakwah Jamaah Tabligh, tersendatnya dakwah ini juga karena faktor struktur dan kesempatan politik masa itu di mana kelembagaan politik berada pada posisi terkunci. Kelembagaan politik yang tertutup akan menghambat, atau bahkan menyumbat kebebasan berpendapat, berekspresi, dan memperjuangkan apa yang dianggap hak dan benar, sehingga hak dan kebenaran menjadi terpasung. ${ }^{79}$ Masa itu adalah mas pemerintahan Orde Baru (Orba) dengan sistem politik tertutupnya yang tidak memberikan ruang yang cukup bagi warga negara untuk berekspresi dan menyuarakan kepentingannya, bahkan pemerintah cenderung bertindak represif serta memata-matai segala bentuk aktivitas apapun, khususnya aktivitas keagamaan, yang dilakukan oleh komunitas atau kelompok masyarakat. ${ }^{80}$

Pemerintah, melalui Pemerintahan Daerah Tingkat Dua (DT II) dalam hal ini Magetan dan Madiun, telah mengambil sikap curiga dan mengawasi segala bentuk kegiatan yang dilakukan oleh Jamaah Tabligh. Pemerintah Madiun bahkan tidak segan melarangnya. Tidak hanya berhenti sampai di sini, untuk melemahkan gerakan dakwah ini, pemerintah menghembuskan isu-isu yang kurang valid atau bahkan tidak benar, di mana mereka menyebarkan berita kepada masyarakat bahwa gerakan dakwah Jamaah Tabligh di Temboro Magetan merupakan dakwah import, tidak sesuai dengan alam dan kondisi masyarakat Indonesia, gerakan dakwah yang mengajak kepada paham

\footnotetext{
${ }^{77}$ Ibid., Vol. 1, 139.

${ }^{78}$ Ibid., 115.

79 Abdul Wahid Situmorang, Gerakan Sosial: Teori dan Praktik (Yogyakarta: Pustaka Pelajar, Cet. 2, 2013), 32-33.

${ }^{80}$ Geert Arend van Klinken, Perang Kota Kecil: Kekerasan Komunal dan Demokratisasi di Indonesia, terj. Bernard Hidayat (Jakarta: Yayasan Obor Indonesia, 2007), 38.
} 
radikal, ekstrem, kekerasan, dan dakwah Jamaah Tabligh adalah gerakan terorisme. $^{81}$

Gencarnya isu yang dihembuskan oleh pemerintah yang didukung oleh sebagian tokoh yang secara pribadi "tidak cocok" dengan Kiai Mahmud dan anaknya, Uzairon, telah berujung pada pemberhentian Uzairon dari jabatan sebagai Ketua Syuriah NU Magetan yang telah diembannya selama dua periode. ${ }^{82}$ Kondisi seperti ini semakin membuat masyarakat, yang secara paham keagamaan mayoritas adalah tradisional (NU), percaya bahwa gerakan dakwah Jamaah Tabligh adalah aliran keras, sesat dan terlarang. Imbasnya, kepercayaan masyarakat semakin berkurang kepada Kiai Mahmud dan anaknya. Efeknya adalah banyak orang tua yang memulangkan anak-anaknya dari Pesantren Al-Fatah yang diasuh oleh Kiai Mahmud. ${ }^{83}$

Lebih jauh, pada periode awal masuknya Jamaah Tabligh, yaitu 1983-1990, di mana isu sesat, radikal, dan terlarang menghinggapi mayoritas masyarakat, membuat sebagian masyarakat, bahkan bertindak yang tidak sepantasnya terhadap Jamaah Tabligh. Para aktivis Jemaah sering mendapatkan cibiran dan cemoohan, bahkan mereka tidak jarang dilempar dengan batu ketika melakukan khurûj fì sabîl Allâh. ${ }^{84}$ Meski demikian, keangkuhan, cibiran dan cemoohan, seperti panggilan "Jemaah Jenggot", "Jemaah Cingkrang", "Jemaah Kompor", "Jemaah Pengembara", dan panggilan-panggilan peyoratif serta gangguan lainnya tidak membuat Jamaah Tabligh Temboro patah semangat. Mereka tetap bergairah dalam melakukan dakwah. Jamaah Tabligh memaklumi kondisi masyarakat yang memang belum tahu banyak informasi tentang komunitas dakwah ini, selain kondisi politik yang saat itu memang kurang mendukung gerakan dakwah mereka.

Prinsip ikrâm al-Muslim gerakan dakwah Jamaah Tabligh memainkan peran yang urgen dalam menghadapi kondisi warga masyarakat Temboro. Mendapatkan respons yang tidak menyenangkan dari masyarakat tidak lantas membuat Jamaah Tabligh marah ataupun menyimpan rasa benci dan terlebih lagi menyerah. Prinsip ikrâm al-Muslim justru membuat Jamaah Tabligh lebih bersikap simpatik terhadap sesama Muslim. Kepada sesama Muslim, Jamaah

\footnotetext{
${ }^{81}$ Dalhari, Sejarah Masuk dan Perkembangan, 45-48.

82 Ibid., 46.

${ }^{83}$ Munir, Pluralisme Madzhab, 158.

${ }^{84}$ Dalhari, Sejarah Masuk dan Perkembangan, 47.
} 
Tabligh senantiasa berusaha memperlihatkan sikap ramah dan santun serta sifat-sifat yang terpuji. ${ }^{85}$ Jamaah Tabligh bahkan lebih suka mengoreksi diri daripada menyalahkan keadaan. Salah satu pertanyaan besar sebagai bentuk auto critique mereka adalah "kira-kira apa sebenarnya terjadi sampai dakwah mereka belum dapat di terima?" 86

Prinsip ikrâm al-Muslim menahan Jamaah Tabligh dari berprasangka buruk kepada sesama Muslim. Kepada seorang Muslim yang dianggap hina dan tersisih sekalipun dalam pandangan umum, Jamaah Tabligh bahkan tetap menghormatinya. Bagi Jamaah Tabligh, percikan keimanan yang ada dalam hati seorang Muslim sudah cukup mulia. Memikirkan anugerah iman yang Allah turunkan kedalam hati seorang Muslim mengalahkan prasangka jelek untuk melihat sikap dan sifat buruk yang ada padanya. Bisa jadi, seorang Muslim yang dianggap lemah dan hina dalam pandangan umum, menurut pandangan Allah ternyata lebih mulia dan tinggi derajatnya. ${ }^{87}$

Sikap tersebut sesuai dengan pesan pendiri Jamaah Tabligh, Maulana Ilyas, yaitu:

Seseorang ketika hendak menghapus kemaksiatan-atau orangorang yang angkuh tidak mau menerima seruan kebaikan-dari kalangan orang-orang Islam, tidak akan tercapai suatu kemajuan jika hanya membicarakannya atau duduk-duduk bersama kemaksiatan atau bersama keangkuhan mereka, yang harus dilakukan adalah dengan membesarkan dan meninggikan sifat baik yang ada pada mereka, maka kemaksiatan dan keangkuhan akan sirna dengan sendirinya. ${ }^{88}$

Sebagaimana prinsip ikrâm al-Muslim yang sudah di jelaskan sebelumnya, Jamaah Tabligh senantiasa berusaha mengaplikasikan prinsip tersebut dalam gerakan dakwah mereka dalam kehidupan sehari-hari di Temboro, bahkan prinsip dari ajaran ikrâm al-Muslim ini barangkali hanya gerakan dakwah Jamaah Tabligh yang secara formal menjadikannya sebagai asas dakwah serta aturan utama dalam dakwah mereka.

Kegigihan dalam berdakwah, kesabaran dan istiqâmah mengamalkan prinsip ikrâm al-Muslim seiring dengan runtuhnya rezim Orde Baru dan memasuki Era Reformasi yang ditandai dengan terbukanya kesempatan berpendapat, menyuarakan aspirasi dan

\footnotetext{
85 An-Nadwi, Sejarah Mubammad Ilyas, 168.

${ }^{86}$ Ibid., 69-71.

87 Ibid., 162.

${ }^{88}$ Ibid., 95.
} 
berekspresi, Jamaah Tabligh menemukan momentum dakwahnya. Masyarakat Temboro mulai terbuka di mana warga tidak hanya menerima seruan dakwah Jamaah Tabligh, melainkan mendukung, dan mengamalkan amalan-amalan yang diserukan oleh Jamaah Tabligh. Sikap-sikap religiositas masyarakat mulai tampak terlihat.

Tanda-tanda sebagai masyarakat religius sangat kental di Temboro. Memasuki lingkungan Desa Temboro, pengunjung akan disambut dengan tulisan "Anda Memasuki Kawasan Berbusana Muslim”. Di pinggir jalan banyak ditemukan plang bertuliskan huruf Arab dan berbahasa Arab. Dalam hal berpakaian, misalnya, baik di rumah atau di pasar-pasar, para wanitanya memakai burqâa' atau tutup wajah dan para lelakinya memakai jubah atau pakaian-pakaian yang panjangnya tidak melebihi mata kaki. Hal lain yang, mungkin, menakjubkan adalah ketika terdengar kumandang suara azan, tanda masuk waktu salat, warga masyarakat Temboro akan segera berhenti sejenak dari apapun aktivitasnya, mulai dari yang berdagang, yang berada di sawah, yang sedang mengajar, yang sedang belajar, dan seterusnya, mereka berduyun-duyun memenuhi masjid dan musala untuk mendirikan salat berjemaah. Masyarakat Temboro sangat antusias untuk meramaikan masjid dan musala-musala mereka. Seorang perempuan Temboro tidak akan membukakan pintu untuk tamu laki-laki yang bukan mahramnya jika dia sedang sendirian di rumahnya. Hal seperti ini sudah menjadi budaya di masyarakat Temboro. Di Indonesia, fenomena gaya hidup, gairah, serta semarak ${ }^{89}$ dan motivasi keberagamaan seperti di atas mungkin hanya bisa ditemukan di Temboro Magetan. ${ }^{90}$

Antusiasme masyarakat kemudian diikuti dengan kesedian mereka untuk mendukung dan membantu kelancaran serta kesuksesan perkembangan Jamaah Tabligh, bahkan mereka juga banyak yang turut serta ikut berdakwah khurûj fì sabîl Allâh. Hal ini semakin menumbuhkan minat hingga menarik banyak Jamaah Tabligh dari berbagai daerah di Indonesia, bahkan dari manca negara, untuk datang ke Temoboro. Masyarakat dengan ikhlas bersedia meminjamkan tanah atau rumah-rumah dan bahkan mereka rela

${ }^{89}$ Disebut semarak karena masyarakat Temboro biasa menghidupkan tradisi-tradisi keagamaan, seperti momentum maulid Nabi Muhammad, Isra' Mi'raj, Muharram, Nuzul al-Qur'ân, dan tradisi Jawa yang telah dibalut dengan nilai-nilai Islam, semisal tingkeban, wolungwulanan, sangangwulanan, slametan untuk mensyukuri nikmat atau memperingati kematian seseorang, dan lain-lainnya. Munir, Pluralisme Madzhab, 115.

${ }^{90}$ Dalhari, Sejarah Masuk dan Perkembangan, 48-50. 
menjual tanah dengan harga yang sangat murah demi semakin majunya gerakan dakwah ini. Sawah-sawah atau perkebunan yang dahulunya biasa ditanami tebu sekarang berubah menjadi sebuah perkampungan yang dikenal dengan kampung Trangkil yang kemudian dijadikan markaz Jamaah Tabligh di Temboro. Langkah tersebut dilakukan karena melihat semakin banyaknya para Jemaah yang datang baik dari daerah-daerah yang ada di Indonesia ataupun dari manca negara, seperti dari Malaysia, Singapura, Filipina, Thailand, Pakistan, Bangladesh, India dan lain-lainnya yang bermukim di sana. ${ }^{91}$

Tidak hanya pada perubahan perilaku dan gaya hidup yang religius, Jamaah Tabligh juga memberikan andil terhadap bertumbuhnya kehidupan ekonomi masyarakat. Banyaknya orang yang datang ke Temboro, sebagaimana telah disebut di atas, telah membuka peluang ekonomi masyarakat Desa Temboro. Perkembangan pendidikan di Temboro, yang ditandai dengan banyaknya lembaga-lembaga pendidikan baik formal ataupun yang non-formal, ${ }^{92}$ secara langsung ataupun tidak juga merupakan dampak positif daripada gerakan dakwah Jamaah Tabligh.

\section{Penutup}

Gerakan dakwah Jamaah Tabligh merupakan gerakan dakwah yang mengusung nilai-nilai humanis yang merupakan pengejawantahan dari salah satu sifat al-sittah (enam sifat) yang menjadi prinsip dakwahnya, yaitu prinsip ikrâm al-Muslim. Dengan prinsip tersebut Jamaah Tabligh mampu beradaptasi dengan berbagai lingkungan dan medan dakwah yang mereka hadapi, tidak terkecuali dalam berdakwah di Temboro dalam membangun masyarakat yang religius. Di masa awal dakwah, walaupun menemukan kondisi yang tidak bersahabat, seperti suasana politik yang kurang mendukung, respons dingin dari tokoh-tokoh masyarakat serta respons dari warga masyarakat yang tidak menyenangkan, tidak membuat Jamaah Tabligh gentar atau kembali surut ke belakang. Mereka tetap gigih, sabar serta istiqâmah dalam memperjuangkan kebenaran dakwah mereka, sehingga sampai kepada hasil yang diinginkan, yaitu peralihan dari masyarakat di mana gairah keberagamaan "kurang hidup" kepada masyarakat yang religius dengan semangat budaya keberagamaan yang tinggi dan semarak. Tidak hanya budaya keberagamaan yang berubah, taraf ekonomi masyarakat Temboro juga ikut berubah di mana awalnya kondisi

${ }^{91}$ Ibid., 50-51.

92 Munir, Pluralisme Madz̧hab, 112-114. 
perekonomian mereka sulit, namun dengan banyaknya orang yang datang ke daerah ini peluang ekonomi perlahan namun pasti terbuka.

\section{Daftar Rujukan}

Aḥmad, Sayf al-Raḥmân. Nažrat 'Âbirah I'tibârîyah ḥawl al-Jamâ'ah alTabligh. t.t: al-Madînah al-Munawwarahh, t.th.

al-Kandahlawi, Maulana Muhammad Yusufh. Muntakhab Ahâdîth:

Dalil-dalil Piliban Enam Sifat, terj. Ahmad Nur Khalis al-Adib dan Mujahid. Yogyakarta: Ash-Shaff, Cet ke-2, 2007.

----. Fadbilah Sedekah, terj. Supriyono Abdullah. Yogyakarta: AshShaff, t.th.

Amin, Edi. "Dakwah Rahmatan li al-'Alamin Jamaah Tabligh di Kota Jambi”, Jurnal Komunikasi Islam, Vol. 2, No. 1, Juni, 2012.

an-Nadwi, Syid Abu Hasan Ali. Sejarah Mubammad Ilyas Menggerakkan Jamaah Tabligh Mempelopori Khuruj Fi Sabilillah. Bandung: Pustaka Ramadhan, 2009.

As-Sirbuni, Abdurrahman Ahmad. Kupas Tuntas Jamaah Tabligh. Cirebon: Pustaka Nabawi, Cet. 3, 2010.

'Asqalânî (al), al-Hafiz Aḥmad b. 'Alî b. Hajr. Fatḥ al-Bârî bi Sharḥ Șahîh al-Bukhârî, Vol. 10, "Kitâb al-Adab", Hadîth 6011. Beirut: Dâr al-Ma'rifah, t.th.

Balasuriya, Tessa. Teologi Sejarah. Jakarta: Gunung Mulia, Cet. ke-3, 2004.

Budimansyah. "Gerakan Islam Jamaah Tabligh dalam Tinjauan Maqasid al-Din", Jurnal Al-'Adalah, Vol. 10, No. 3, 2012.

Dalhari, Rowi. Sejarah Masuk dan Perkembangan Jamaah Tabligh di Temboro Magetan. Surabaya: UINSA, 2014.

Ditjenbud, Tim. Strategi Pembinaan dan Pengembangan Kebudayaan Indonesia. Jakarta: Direktorat Jenderal Kebudayaan, 2000.

Hamzah. Khittah NU, dalam www.nu.or.id diakses 17 Oktober 2016. Hasanah, Umdatul. "Keberadaan Kelompok Jamaah Tabligh dan Reaksi Masyarakat: Perspektif Teori Penyebaran Informasi dan Pengaruh", Jurnal Indo-Islamika, Vol. 4, No. 1, Januari-Juni, 2014. Hendropuspito. Sosiologi Agama. Yogyakarta: Kanisius, Cet. 22, 2006. Ilahi, Maulana Asyiq. Enam Sifat Sahabat R.A. Yogyakarta: Ash-Shaff, 1995.

Jum'ah, 'Alî. Al-Mutshaddidûn: Manbajubum, wa Munâqashat Ahamm Qậââhum (Kairo: Dâr al-Maqțam li al-Nashr wa al-Tawzî', 2012. Jurdi, Syarifuddin. Sosiologi Islam: Elaborasi Pemikiran Sosial Ibn Khaldun. Yogyakarta: Teras, 2008. 
Khoirun, A. Meneruskan Tradisi Dakwah Para Pendabulu, dalam www.nu.or.id diakses 17 Oktober 2016.

Klinken, Geert Arend van. Perang Kota Kecil: Kekerasan Komunal dan Demokratisasi di Indonesia, terj. Bernard Hidayat. Jakarta: Yayasan Obor Indonesia, 2007.

Knitter, Paul F. Satu Bumi Banyak Agama: Dialog Multi-Agama dan Tanggung Jawab Global. Jakarta: Gunung Mulia, 2008.

Liem, Koko. The Power Husnuz Zan: Berbaik Sangkalah Maka Hidupmu Akan Barokah. Jakarta: Penebar Swadaya Group, 2012.

Mahmud, Ali Abdul Halim. Dakwah Fardiyah: Membentuk Pribadi Muslim, terj. As'ad Yasin. Jakarta: Gema Insani Press, Cet. 2, 2004.

Meera, Ahmed Kameel Mydin. Perampok Bangsa-Bangsa: Mengapa Emas Harus Jadi Uang Internasional, terj. Yulizar Djamaluddin Sanrego NZ. Jakarta: Penerbit Mizan, 2010.

Munir, Samsul. Pluralisme Madz̧ab Dakwah Jamaah Tabligh di Kampung Madinah. Yogyakarta: Pustaka Ilmu, 2015.

Rifấî (al), Muhammad Nâsib. Taysîr al-'Alî al-Qadîr: Ikbtișâr Tafsîr Ibn Kathîr. Riyâd: Maktabah al-Ma'ârif, 1989.

Setiawan, Zudi. Nasionalisme NU. t.t.: Aneka Ilmu, 2007.

Shahab, An-Nadhr M. Ishaq. Khuruj Fi Sabilillab: Sarana Tarbiyah Umat untuk. Membentuk Sifat Imaniyah. Bandung: Pustaka Al-Ishlah, t.th.

Situmorang, Abdul Wahid. Gerakan Sosial: Teori dan Praktik, Cet. 2. Yogyakarta: Pustaka Pelajar, 2013.

Soetomo. Pembangunan Masyarakat: Merangkai sebuah Kerangka. Yogyakarta: Pustaka Pelajar, Cet. 2, 2012.

Sugiharto, I. Bambang dan Rachmat W., Agus. Wajah Baru Etika dan Agama. Yogyakarta: Penerbit Kanisius, Cet. 5, 2004.

Temboro, Pesantren Al-Fatah. Mudzakarah Dakwah Usaha Rasulullah SAW. Magetan: Maktabah Al-Barakah, 2012.

Wahyudin dkk. Pendidikan Agama Islam untuk Perguruan Tinggi. Jakarta: Grasindo, 2009.

Yayasan Pendidikan Al-Fatah, Enam Sifat Doa Hidayah. Magetan: Yayasan Pendidikan Al-Fatah, t.th. 